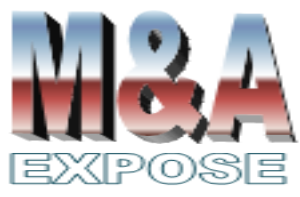

http://jurnal.usahid.ac.id/index .php/accounting
${ }^{1}$ Fakultas Ekonomi dan Bisnis Perbanas Institute f.sorongan@perbanas.id

\section{Pengaruh Peringkat Obligasi, Maturity, dan Likuiditas terhadap Yield To Maturity pada Perusahaan Terbuka di Indonesia}

\section{Fanky Sorongan ${ }^{1}$}

\section{Abstrak}

Tujuan dari penelitian ini adalah untuk mengetahui pengaruh Peringkat Obligasi, Maturity, dan Yield to Maturity terhadap Maturitas Obligasi Korporasi yang terdaftar di Bursa Efek Indonesia untuk periode 2014-2017. Penelitian ini termasuk penelitian asosiatif (hubungan), yaitu penelitian yang bertujuan untuk mengetahui hubungan dua variabel atau lebih. Metode pengambilan sampel adalah purposive sampling dan sesuai dengan kriteria yang ditentukan. Hasil penelitian ini adalah ada pengaruh yang signifikan peringkat obligasi terhadap yield obligasi hingga jatuh tempo sebesar 32,43 persen. Selain itu, ada pengaruh signifikan jatuh tempo pada Obligasi Yield to Maturity sebesar 20,89 persen. Dan terakhir ada pengaruh yang signifikan dari Obligasi, Maturity, dan Yield to Maturity Bonds sebesar 0,14 persen.

Kata kunci : Peringkat Obligasi, Maturity, Yield To Maturity Bond.

\section{Abstract}

The purpose of this study was to determine the effect of Bond, Maturity and Liquidity Rating on Yield to Maturity of Corporate Bonds listed on the Indonesia Stock Exchange for the 2014-2017 period. This research includes associative research (relationship), which is research that aims to determine the relationship of two or more variables. The sampling method was purposive sampling and in accordance with the specified criteria. The results of this study are that there is a significant effect of bond rating on bond yield to maturity of 32.43 percent. Furthermore, there is a significant effect of Maturity on Bond Yield to Maturity of 20.89 percent. And lastly there is a significant influence of Bond, Maturity and Liquidity Rating on Yield to Maturity Bonds of 0.14 percent.

Keywords: Bond, Maturity and Liquidity Rating, Yield To Maturity Bond. 


\section{PENDAHULUAN}

Pasar modal adalah pasar jangka panjang yang di dalamnya terdapat berbagai macam instrumen pasar modal yang dapat dijadikan pertimbangan oleh pihak pemodal. Di sisi lain pasar modal juga merupakan pasar yang mempertemukan antara pihak yang membutuhkan dana dan pihak yang memerlukan dana jangka panjang. Dilihat dari peluang investasi Indonesia setiap tahunnya, rata-rata peluang investasi mengalami peningkatan dari tahun ke tahun (Sorongan, 2017). Bahkan di saat perekonomian global mengalami perlambatan, investasi menjadi salah satu komponen utama penopang pertumbuhan ekonomi menggantikan kinerja ekspor yang cenderung melambat. Ini membuktikan bahwa aktivitas investasi Indonesia patut untuk dijadikan perhatian utama, baik pada saat perekonomian negara memburuk maupun pada saat perekonomian negara membaik.

Pasar obligasi memerankan peran penting sebagai salah satu alternatif sumber pembiayaan di masa pertumbuhan ekonomi dunia dewasa kini. Setelah krisis keuangan Asia pada 1997, pemerintah telah memulai secara aktif utilisasi obligasi sebagai sumber utama bagi pembiayaan jangka panjang guna penguatan sistem keuangan suatu negara dan mengurangi potensi guncangan krisis keuangan di masa mendatang. Pemerintah Indonesia memandang perlu untuk menutup defisit anggaran belanja pemerintah melalui pinjaman yang bersumber dari dalam negeri. Obligasi merupakan surat hutang yang diterbitkan oleh pemerintah maupun pihak swasta kepada masyarakat dengan imbalan berupa kupon atau bunga dan pelunasan pokok dibayarkan lebih dari satu tahun. Pembayaran kupon bisa dilakukan secara periodik baik bulanan, triwulanan atau tengah tahunan (Samsul, 2015).

Obligasi sebagai suatu instrumen investasi menawarkan yield bagi investor. Yield obligasi adalah faktor terpenting pertimbangan investor dalam melakukan pembelian obligasi sebagai instrumen investasinya. Yield obligasi merupakan ukuran pendapatan obligasi yang akan diterima oleh investor, yang cenderung bersifat tidak tetap. Yield obligasi tidak bersifat tetap, sebagaimana layaknya bunga obligasi, karena yield obligasi akan sangat terkait dengan tingkat return yang diisyaratkan investor. Sedangkan Samsul (2015) menyatakan bahwa yield adalah keuntungan atas investasi obligasi yang dinyatakan dalam persentase. Fabozzi (2000) menyatakan bahwa ada beberapa ukuran yield obligasi yang dapat digunakan oleh investor, yaitu current yield dan yield to maturity (YTM).

Brigham (2010) menyatakan bahwa yield to maturity merupakan tingkat keuntungan yang akan diterima investor jika membeli obligasi pada harga pasar saat ini dan menahan obligasi tersebut hingga jatuh tempo. Seorang investor yang membeli suatu obligasi dan memilikinya sampai obligasi itu jatuh tempo akan menerima yield to maturity yang terdapat pada tanggal pembelian, tetapi yield to maturity obligasi yang diperhitungkan akan sering mengalami perubahan diantara tanggal pembelian dan tanggal jatuh temponya.

Yield to maturity dapat diartikan sebagai tingkat return majemuk yang akan diterima investor jika membeli obligasi pada harga pasar saat ini dan menahan obligasi tersebut hingga jatuh tempo. Tandelilin (2010) menyatakan bahwa yield to maturity merupakan ukuran yield yang banyak digunakan karena yield tersebut mencerminkan return dengan tingkat bunga majemuk (compound rate of return) yang diharapkan investor.

Tujuan investor berinvestasi adalah untuk mendapatkan keuntungan berupa pembayaran kupon obligasi dan capital gain. Capital gain diperoleh pada saat melakukan penjualan terhadap obligasi yang dipegang oleh investor (Nasher dan Surya, 2011). 
Dalam prakteknya investor belum tahu sepenuhnya berbagai faktor yang mempengaruhi yield obligasi. Padahal dengan mengetahui faktor-faktor yang dapat mempengaruhi yield obligasi, investor dapat memaksimalkan imbal hasilnya. Seperti imbal hasil saat jatuh tempo juga dapat dilihat sebagai tingkat pengembalian obligasi yang dijanjikan. Hal itu merupakan pengembalian yang akan diterima investor jika seluruh pembayaran yang dijanjikan terlaksana. Akan tetapi, yield to maturity hanya akan sama dengan tingkat pengembalian yang diharapkan jika probabilitas gagal bayar adalah nol serta obligasi tidak dapat ditebus. Oleh karena itu, investor dan emiten harus selalu memperhatikan faktor-faktor yang mempengaruhi perubahan yield obligasi tersebut.

Seorang investor yang hendak membeli obligasi tentunya harus memperhatikan peringkat obligasi (credit ratings). Peringkat obligasi sangat berguna bagi calon investor yang akan menanamkan modalnya dalam bentuk obligasi karena dengan melihat peringkat ini investor dapat mengetahui kemungkinan return yang akan diperoleh dan risiko yang harus ditanggungnya. Semakin tinggi peringkat obligasi, semakin menunjukkan bahwa obligasi tersebut terhindar dari risiko default. Sebaliknya jika semakin rendah peringkat obligasi, semakin tinggi risiko default, semakin tinggi juga imbal hasil yang diberikan (Indarsih, 2013).

Maturity (jangka waktu jatuh tempo) juga diduga memiliki pengaruh terhadap yield to maturity. Hal tersebut dikarenakan total arus kas yang diterima investor akan sangat bergantung pada umur investasi tersebut. Obligasi yang memiliki periode jatuh tempo lebih lama maka akan memiliki tingkat risiko yang lebih tinggi sehingga yield yang didapatkan juga berbeda dengan obligasi yang umur jatuh temponya cukup pendek (Surya dan Nasher, 2011).

Permasalahan yang dihadapi oleh pasar obligasi Indonesia saat ini adalah masih banyaknya pasar yang menyebabkan rendahnya likuiditas, terutama yang dialami obligasi korporasi, serta masih rendahnya tingkat likuiditas perusahaan. Likuiditas perusahaan sangat penting dalam mempengaruhi yield obligasi. Semakin tinggi tingkat likuiditas perusahaan, maka semakin rendah risiko gagal bayarnya. Likuiditas perusahaan yang tinggi akan menyebabkan obligasi lebih menarik karena tersedianya pembeli dan penjual yang lebih banyak sehingga pihak yang memiliki obligasi dapat menjual obligasinya kapan saja (Favero et al., 2010).

Krisnilasari (2007) dari hasil penelitianya menunjukan bahwa variabel likuiditas berpengaruh negatif signifikan terhadap peringkat obligasi. Sedangkan penelitian yang dilakukan oleh Fauzani (2017) menyatakan bahwa variabel peringkat obligasi berpengaruh negatif dan tidak signifikan. Sedangkan variabel maturitas dan variabel profitabilitas tidak berpengaruh signifikan terhadap yield obligasi.

Selanjutnya penelitian yang dilakukan oleh Pinanditha (2016) menunjukkan hasil penelitian bahwa profitabilitas, maturity dan jaminan berpengaruh positif dan signifikan terhadap peringkat obligasi, sedangkan likuiditas berpengaruh negatif dan signifikan terhadap peringkat obligasi. Penelitian oleh Nurfauziah dan Setyarini (2004) menyatakan bahwa likuiditas berpengaruh positif terhadap yield to maturity yang berarti semakin tinggi likuiditas, maka semakin tinggi yield to maturity. Hal tersebut bertolak belakang dengan penelitian yang dilakukan oleh Favero et al. (2007) yang menyatakan bahwa likuiditas berpengaruh negatif terhadap yield to maturity yang berarti bahwa semakin tinggi likuiditas maka akan semakin rendah yield to maturity yang diterima. 
Berdasarkan latar belakang tersebut, maka penelitian ini bertujuan menganalisis pengaruh peringkat obligasi, maturity, dan likuiditas terhadap yield to maturity obligasi pada perusahaan publik di Bursa Efek Indonesia.

\section{TINJAUAN PUSTAKA}

Obligasi. Obligasi adalah kontrak jangka panjang di mana peminjam setuju untuk melakukan pembayaran bunga dan pokok pinjaman, pada tanggal tertentu, kepada pemegang obligasi (Brigham, 2010). Obligasi merupakan surat utang yang dikeluarkan oleh emiten (badan hukum/perusahaan atau pemerintah) yang memerlukan dana untuk kebutuhan operasi maupun ekspansi mereka. Investasi pada obligasi memiliki potensial keuntungan lebih besar daripada produk perbankan. Keuntungan berinvestasi di obligasi adalah memperoleh bunga dan kemungkinan adanya capital gain. Secara umum dapat juga diartikan obligasi adalah surat utang jangka panjang yang diterbitkan oleh suatu lembaga, dengan nominal dan waktu jatuh tempo tertentu. Penerbit obligasi bisa perusahaan swasta, BUMN atau pemerintah, baik pemerintah pusat maupun daerah. Salah satu jenis obligasi yang diperdagangkan di pasar modal saat ini adalah obligasi kupon (coupon bond) dengan tingkat bunga tetap (fixed) selama masa berlaku obligasi (Pinanditha, 2016).

Yield Obligasi. Raharja (2008) menyatakan bahwa yield obligasi merupakan faktor terpenting sebagai pertimbangan investor dalam melakukan pembelian obligasi sebagai instrumen investasinya. Investor obligasi akan menghitung seberapa besar pendapatan investasi atas dana yang dibelikan obligasi tersebut dengan menggunakan alat ukur yield. Menurut Fabozzi (2000) dalam Setyapurnama dan Norpratiwi (2008) menyatakan bahwa terdapat dua istilah dalam penentuan yield, yaitu current yield dan yield to maturity.

Maturity. Maturity (maturitas) merupakan periode jatuh tempo untuk melunasi seluruh pinjaman yang telah disepakati. Maturity sebuah obligasi sekaligus digunakan untuk menunjukkan umur obligasi tersebut, biasanya maturity obligasi dinyatakan dalam bentuk tahunan. Obligasi yang memiliki waktu jatuh tempo yang lebih lama maka akan memiliki tingkat risiko yang lebih tinggi, begitu pula sebaliknya. Oleh karena itu, investor lebih menyukai untuk membeli obligasi yang memiliki waktu jatuh tempo yang lebih pendek.

Selain itu, panjang atau pendeknya waktu jatuh tempo dalam obligasi juga akan mempengaruhi harga obligasi tersebut karena adanya perubahan suku bunga yang bergerak fluktuatif. Tandelilin (2010) menjelaskan apabila terjadi penurunan (kenaikan) tingkat bunga, maka harga obligasi akan naik (turun), tetapi persentase perubahan harga yang relatif lebih besar akan terjadi pada obligasi yang mempunyai maturity yang lebih panjang dan tingkat kupon yang lebih rendah. Maka dari itu, adanya obligasi dengan maturity tertentu bisa dijadikan pilihan investor untuk menghindari adanya kerugian bila suatu saat suku bunga mengalami penurunan.

Likuiditas. Likuiditas obligasi merupakan sebuah indikator dari seberapa mudahnya sebuah obligasi yang dipegang oleh para pemilik modal untuk dijadikan kas pada pasar sekunder. Definisi lain menyatakan bahwa obligasi merupakan suatu istilah yang dipergunakan dalam dunia keuangan yang merupakan suatu pernyataan utang dari penerbit obligasi kepada pemegang obligasi beserta janji untuk membayar kembali pokok utang beserta kupon bunganya kelak pada saat tanggal jatuh tempo pembayaran. 
Likuiditas pasar obligasi membahas antara lain adalah likuiditas pasar modal secara umum. Definisi yang baku tentang likuiditas pasar modal belum ada, akan tetapi dari arti kata likuiditas dan pasar modal yang sudah ada dapat disimpulkan bahwa yang dimaksud dengan likuiditas pasar modal adalah kemudahan sebuah efek untuk diperjualbelikan di bursa efek dengan tidak mengalami perubahan harga yang tajam. Likuiditas pasar modal juga dapat diartikan sebagai volume dan frekuensi transaksi yang terjadi di pasar modal.

Pengembangan Hipotesis. Berdasarkan landasan teori dan temuan-temuan peneliti terdahulu, maka hipotesis yang diajukan oleh peneliti adalah:

$\mathrm{H}_{1}=$ Peringkat Obligasi berpengaruh signifikan terhadap Yield To Maturity Obligasi.

$\mathrm{H}_{2}=$ Maturity berpengaruh signifikan terhadap Yield To Maturity Obligasi.

$\mathrm{H}_{3}=$ Likuiditas berpengaruh signifikan terhadap Yield To Maturity Obligasi.

\section{METODE PENELITIAN}

Variabel Penelitian. Variabel dependen dalam penelitian ini adalah yield to maturity obligasi. Sedangkan variabel independen adalah peringkat obligasi, maturity, dan likuiditas. Unit analisis dalam penelitian ini adalah perusahaan yang menerbitkan obligasi dan terdaftar di Bursa Efek Indonesia (BEI) selama periode tahun 2014 sampai dengan 2017. Pengambilan sampel dalam penelitian ini dilakukan dengan menggunakan metode purposive sampling, menggunakan data time series.

Populasi dan Sampel. Populasi dalam penelitian ini adalah semua perusahaan yang menerbitkan obligasi, yang terdaftar di Bursa Efek Indonesia (www.idx.co.id) periode 2014-2017. Sampel pada penelitian ini semua jenis obligasi yang diterbitkan perusahaan yang terdaftar di Bursa Efek Indonesia periode 2014-2017.

Pengambilan sampel dalam penelitian ini menggunakan teknik purposive sampling yaitu pengambilan sampel yang bertujuan untuk mengambil sampel dari populasi berdasarkan kriteria tertentu (Ghozali, 2013). Adapun kriteria sampel dalam penelitian ini adalah sebagai berikut :

1. Obligasi yang diterbitkan perusahaan yang terdaftar di BEI dan termasuk obligasi yang belum jatuh tempo.

2. Obligasi yang diterbitkan perusahaan baik sektor keuangan maupun nonkeuangan dan bukan termasuk dalam obligasi syariah.

3. Obligasi pada perusahaan yang mengeluarkan laporan keuangan lengkap dan beredar pada periode 1 Januari 2014 sampai dengan 31 Desember 2017.

4. Obligasi yang memiliki peringkat yang dikeluarkan dari lembaga pemeringkat efek PT. Pefindo.

5. Obligasi yang memiliki data berupa harga, kupon, nominal, dan jatuh tempo obligasi.

Berdasarkan kriteria-kriteria yang telah ditetapkan dari tahun 2014 hingga tahun 2017 terdapat 23 perusahaan dari 45 perusahaan yang terdaftar di Bursa Efek Indonesia.

Teknik Analisis. Metode analisis yang digunakan adalah regresi linier berganda dengan persamaan sebagai berikut:

$$
Y=a+\beta_{1} X_{1}+\beta_{2} X_{2}+\beta_{3} X_{3+} \varepsilon
$$




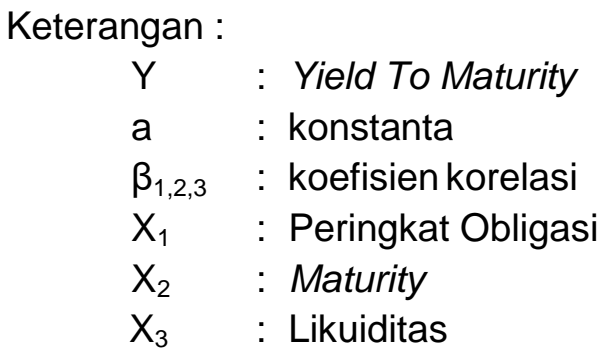

HASIL DAN PEMBAHASAN

Tabel 1. Analisis Regresi Linier Berganda

\begin{tabular}{|c|c|c|c|c|}
\hline \multicolumn{5}{|c|}{$\begin{array}{l}\text { Dependent Variable: YTM } \\
\text { Method: Least Squares } \\
\text { Date: 08/23/18 Time: 18:29 } \\
\text { Sample: } 20142017 \\
\text { Included observations: } 92\end{array}$} \\
\hline Variable & Coefficient & Std. Error & t-Statistic & Prob. \\
\hline C & 11.69001 & 0.445006 & 26.26933 & 0.0000 \\
\hline PERINGKAT_OBLIG & -0.324346 & 0.047339 & -6.851581 & 0.0000 \\
\hline MATURITY & 0.208902 & 0.059464 & 3.513064 & 0.0007 \\
\hline LIKUIDITAS & -0.001378 & 0.000654 & -2.107665 & 0.0379 \\
\hline R-squared & 0.432484 & \multicolumn{2}{|c|}{ Mean dependent var } & 9.905068 \\
\hline Adjusted R-squared & 0.413137 & \multirow{2}{*}{\multicolumn{2}{|c|}{$\begin{array}{l}\text { S.D. dependent var } \\
\text { Akaike info criterion }\end{array}$}} & 1.363266 \\
\hline S.E. of regression & 1.044357 & & & 2.967184 \\
\hline Sum squared resid & 95.97995 & \multicolumn{2}{|c|}{ Schwarz criterion } & 3.076827 \\
\hline Log likelihood & -132.4905 & \multirow{2}{*}{\multicolumn{2}{|c|}{$\begin{array}{l}\text { Hannan-Quinn criter. } \\
\text { Durbin-Watson stat }\end{array}$}} & 3.011437 \\
\hline F-statistic & 22.35391 & & & 0.906394 \\
\hline Prob(F-statistic) & 0.000000 & & & \\
\hline
\end{tabular}

Sumber : Data diolah, 2018.

Berdasarkan Tabel 1 didapatkan model regresi linier berganda sebagai berikut : $Y=11.69001-0.324346 X_{1}+0.208902 X_{2}-0.001378 X_{3}$

Berdasarkan persamaan regresi linier berganda tersebut dapat diinterpretasikan bahwa :

1. Koefisien regresi Peringkat Obligasi bernilai -0.324346 , artinya ketika Peringkat Obligasi meningkat sebesar 32,43 persen maka akan menyebabkan penurunan Yield To Maturity Obligasi 1 persen.

2. Koefisien regresi Maturity sebesar 0.208902 , artinya ketika Maturity meningkat 20,89 persen maka akan menyebabkan peningkatan Yield To Maturity Obligasi 1 persen.

3. Koefisien regresi Likuiditas sebesar -0.001378 , artinya ketika Likuiditas meningkat sebesar 0.14 persen maka akan menyebabkan penurunan Yield To Maturity Obligasi 1 persen.

Dari Tabel 1 terlihat bahwa nilai signifikan $F=0,000$ maka, signifikansi $F=0,000<$ $\mathrm{a}=0,05$ dengan demikian Ho ditolak, artinya ada pengaruh yang signifikan dari variabel independen terhadap variabel dependen. Berdasarkan hal tersebut dapat disimpulkan bahwa Peringkat Obligasi, Maturity dan Likuiditas merupakan model yang layak.

Uji t. Uji statistik t pada dasarnya menunjukkan seberapa jauh pengaruh satu variabel penjelas atau independen secara individu dalam menerangkan variasi variabel 
dependen (Ghozali, 2011). Adapun hasil analisa uji t-Test dalam penelitian ini ditunjukkan pada tabel berikut:

Tabel 2. Hasil Uji t

\begin{tabular}{|c|c|c|c|c|}
\hline \multicolumn{5}{|c|}{$\begin{array}{l}\text { Dependent Variable: YTM } \\
\text { Method: Least Squares } \\
\text { Date: 08/23/18 Time: 18:29 } \\
\text { Sample: } 20142017 \\
\text { Included observations: } 92\end{array}$} \\
\hline Variable & Coefficient & Std. Error & t-Statistic & Prob. \\
\hline $\mathrm{C}$ & 11.69001 & 0.445006 & 26.26933 & 0.0000 \\
\hline PERINGKAT_OBLIG & -0.324346 & 0.047339 & -6.851581 & 0.0000 \\
\hline MATURITY & 0.208902 & 0.059464 & 3.513064 & 0.0007 \\
\hline LIKUIDITAS & -0.001378 & 0.000654 & -2.107665 & 0.0379 \\
\hline R-squared & 0.432484 & \multicolumn{2}{|c|}{ Mean dependent var } & 9.905068 \\
\hline Adjusted R-squared & 0.413137 & \multirow{2}{*}{\multicolumn{2}{|c|}{$\begin{array}{l}\text { S.D. dependent var } \\
\text { Akaike info criterion }\end{array}$}} & 1.363266 \\
\hline S.E. of regression & 1.044357 & & & 2.967184 \\
\hline Sum squared resid & 95.97995 & \multicolumn{2}{|c|}{ Schwarz criterion } & 3.076827 \\
\hline Log likelihood & -132.4905 & \multirow{2}{*}{\multicolumn{2}{|c|}{$\begin{array}{l}\text { Hannan-Quinn criter. } \\
\text { Durbin-Watson stat }\end{array}$}} & 3.011437 \\
\hline F-statistic & 22.35391 & & & 0.906394 \\
\hline Prob(F-statistic) & 0.000000 & & & \\
\hline
\end{tabular}

Sumber : Data diolah, 2018.

Dari Tabel 2 terlihat bahwa nilai signifikansi t untuk Peringkat Obligasi sebesar 0,000. Berdasarkan kriteria penerimaan dan penolakan hipotesis, signifikansi $t=0,000<a=0,05$, dengan demikian Ho ditolak, artinya terdapat pengaruh signifikan secara parsial dari Peringkat Obligasi terhadap Yield To Maturity Obligasi. Semakin tinggi Peringkat Obligasi, maka semakin rendah risiko gagal bayarnya. Rendahnya risiko gagal bayar akan membuat obligasi lebih diminati investor sehingga harga obligasi akan naik. Harga obligasi yang terus meningkat akan menyebabkan yield obligasi menurun karena tingkat risikonya lebih rendah. Hasil penelitian ini sesuai dengan penelitian Purnamawati (2013) yang menunjukkan bahwa Yield To Maturity Obligasi dipengaruhi oleh Peringkat Obligasi.

Nilai signifikansi t untuk Maturity sebesar 0,0007. Berdasarkan kriteria penerimaan dan penolakan hipotesis, signifikansi $\mathrm{t}=0,000<\mathrm{a}=0,05$, dengan demikian Ho ditolak, artinya terdapat pengaruh signifikan secara parsial dari Maturity terhadap Yield To Maturity Obligasi. Hal ini dikarenakan obligasi yang memiliki maturity lebih lama, akan mengakibatkan harga obligasi menjadi turun dan menyebabkan yield obligasi meningkat. Semakin pendek maturity suatu obligasi, maka harga obligasi akan naik dan yield obligasi akan mengalami penurunan. Hasil penelitian ini sesuai dengan penelitian Purnamawati (2013) yang menunjukkan bahwa Yield To Maturity Obligasi dipengaruhi oleh maturity.

Nilai signifikansi t untuk Likuiditas sebesar 0,0379. Berdasarkan kriteria penerimaan dan penolakan hipotesis, signifikansi $\mathrm{t}=0,000<\mathrm{a}=0,05$, dengan demikian Ho ditolak, artinya terdapat pengaruh signifikan secara parsial dari Likuiditas terhadap Yield To Maturity Obligasi. Dengan terpenuhi kewajibannya, obligasi menjadi lebih menarik karena tersedianya banyak pembeli dan penjual, dan harga obligasi tersebut cenderung stabil dan meningkat. Harga obligasi yang terus meningkat akan menyebabkan yield obligasi menurun karena tingkat risikonya lebih rendah. Hasil penelitian ini sesuai dengan penelitian 
Purnamawati (2013) yang menunjukkan bahwa Yield To Maturity Obligasi dipengaruhi oleh likuiditas.

Estimasi Adjusted R-squared sebesar 0,432484 atau 43,24\%. Hal ini berarti nilai yield to maturity yang mampu dijelaskan oleh variabel Peringkat Obligasi, Maturity, dan Likuiditas sebesar 43,24 persen, sedangkan sisanya 56,76 persen dijelaskan oleh faktorfaktor lain di luar model penelitian ini.

\section{KESIMPULAN}

Berdasarkan analisis pembahasan dan interpretasi yang telah disampaikan, dapat disimpulkan bahwa model penelitian ini merupakan model yang layak. Peringkat Obligasi, Maturity, dan Likuiditas berpengaruh signifikan terhadap Yield To Maturity Obligasi.

Penelitian selanjutnya sebaiknya menganalisis variabel independen yang berbeda dari variabel yang telah diteliti sehingga dengan demikian pengaruh variabel lain sebesar 56,76 persen dapat memperkuat model penelitian. Selain itu, hendaknya penelitian selanjutnya juga memperpanjang periode penelitian untuk memperbanyak jumlah sampel sehingga diharapkan hasil penelitian lebih akurat.

\section{DAFTAR PUSTAKA}

Brigham dan Houston. 2010. Dasar-dasar Manajemen Keuangan. Buku 1 (edisi II). Jakarta: Salemba Empat.

Fabozzi, Frank J. 2000. Manajemen Investasi. Buku Dua. Jakarta : Salemba Empat.

Favero, Carlo., Pagano, Marco., and E.V. Thadden. 2010. How Does Liquidity Affect Government Bond Yields? Journal of Financial and Quantitative Analysis. Vol. 45, No.1.

Fauzani, Windy dan Yahya. 2017. Faktor-faktor yang Mempengaruhi Yield Obligasi. Jurnal IImu dan Riset Manajemen. Sekolah Tinggi Ilmu Ekonomi Indonesia Surabaya (STIESIA).

Ghozali, Imam. 2013. Aplikasi Analisis Multivariate dengan Program IBM SPSS 21. Edisi Ketujuh. Semarang : Badan Penerbit Universitas Diponegoro.

Indarsih, Nanik. 2013. Pengaruh Tingkat Suku Bunga SBI, Rating, Likuiditas Dan Maturitas Terhadap Yield To Maturity Obligasi. Jurnal IImu Manajemen. Vol. 1, No. 1.

Jogiyanto, Hartono. 2010. Teori Portofolio dan Analisis Investasi. Edisi Kedua. Yogyakarta: BPFE.

Krisnilasari, Monica. 2007. Analisis Pengaruh Likuiditas Obligasi, Coupon dan Jangka Waktu Jatuh Tempo Obligasi Terhadap Perubahan Harga Obligasi Di Bursa Efek Surabaya. Tesis. Magister ManajemenUniversitas Diponegoro.

Nasher dan Surya. 2011. Analisis Pengaruh Tingkat Suku Bunga SBI, Exchange Rate, Ukuran Perusahaan, Debt to Equity Ratio, dan Bond terhadap Yield Obligasi Korporasi di Indonesia. Jurnal Manajemen Teknologi. Institut Teknologi Bandung. Vol. 10, No.2. 
Nurfauziah dan Setyarini, Adistien Fatma. 2004. Analisis Faktor-Faktor yang Mempengaruhi Yield Obligasi Perusahaan (Studi Kasus Pada Industri Perbankandan Industri Finansial). Jurnal Siasat Bisnis. Vol.2, No. 9.

Pinanditha, A. W., dan Suryantini, N. S. 2016. Pengaruh Profitabilitas, Rasio Solvabilitas, Ukuran Perusahaan dan Reputasi Auditor Terhadap Peringkat Obligasi Pada Sektor Perbankan. E-Jurnal Manajemen. Vol. 5.

Purnamawati, I Gusti. 2013. Pengaruh Peringkat Obligasi, Tingkat Suku Bunga Sertifikat Bank Indonesia, Rasio Laverage, Ukuran Perusahaan dan Umur Obligasi Pada Imbal Hasil Obligasi Korporasi di Bursa Efek Indonesia. Vokasi Jurnal Riset Akuntansi, Vol. 2, No. 1.

Raharja, dan Sari. 2008. Kemampuan Rasio Keuangan Dalam Memprediksi Peringkat Obligasi (PT Kasnic Credit Rating). Jurnal Maksi. Vol. 8, No.2.

Samsul, M. 2015. Pasar Modal dan Manajemen Portofolio. Jakarta : Erlangga.

Setyapurnama, Y.S. \& Norpratiwi, A.M.V. 2008. Pengaruh Corporate Governance Terhadap Peringkat Obligasi dan Yield Obligasi. Jurnal Maksi. Vol. 8, No.2.

Sorongan, F. A. 2017. Analisis Pengaruh Car, Loan, GDP Dan Inflasi Terhadap Profitabilitas Bank Di Indonesia. Jurnal Akuntansi, Vol. 10, No. 2.

Tandelilin, Eduardus. 2010. Portofolio dan Investasi. Yogyakarta: Kanisius Media. 